\title{
Gastro Hepatic Protective Effects of Sildenafil in $\gamma$-Irradiated Rats
}

\section{S. S. Tawfik and S. F. Salama}

Health Radiation Research and Radiation Biology Dept., National Centre for Radiation Research and Technology (NCRRT), P. O. Box; 29 Nasr City, Egypt.

IILDENAFIL is a potent specific inhibitor of phosphodiestrase-5 (PDE-5), which ultimately increases intracellular cyclic guanosine monophosphate (cGMP). Sildenafil commercially named Viagra; was studied for its gastro hepatic protective activity through acute exposure of rats to $\gamma$-rays.

The experimental groups of rats were: Sildenafil $[1 \mathrm{mg} / \mathrm{kg}$, intra venous (i.v.), in $0.2 \mathrm{ml}$ saline] / day for 5 days and then exposed to 6 Gy $\gamma$-rays after $1 \mathrm{~h}$ of the last injection (sildenafil $+\gamma$-rays group). Controls received saline as a vehicle/ for 5 day; sildenafil group received drug alone for 5 days, and $\gamma$-rays group received saline (without drug) for 5 days and exposed to 6 Gy $\gamma$-rays after $1 \mathrm{~h}$ of the last injection. All groups were decapitated on the $6^{\text {th }}$ day.

Gamma rays increased the level of malondialdehyde (MDA) and the activity of myeloperoxidase (MPO) but, lowered the levels of nitric oxide (NO) and reduced glutathione (GSH) as well as lowering the activities of superoxide dismutase (SOD) and catalase (CAT) in both stomach and hepatic tissues.

Sildenafil administrated before $\gamma$-rays significantly reduced the level of MDA and the activity of MPO while elevating levels of NO and GSH plus activities of SOD and CAT in both stomach and hepatic tissues compared to control and sildenafil groups.

Conclusion: The data reveals that sildenafil pre-treatment has a protective effect against $\gamma$-rays-induced gastro hepatic dysfunction and supports the possible use of sildenafil as a protective agent in $\gamma$-irradiated rats.

Keywords: Silenafil, stomach, liver, $\gamma$-rays, rats.

Several studies have shown that, in addition to treating erectile dysfunction, sildenafil can prevent or decrease tissue injury. In vivo and in vitro, early treatment with sildenafil ameliorated the progression of renal damage in partial nephrectomy (Rodriguez-Iturbe et al., 2005) and provided a protection against heart ischemic injury in man (Khan et al., 2012). In addition, administration of 
sildenafil may be useful against ischemic injury in liver, stomach and lung (Duffin et al., 2008, Eriksson et al., 2011 and Liu and Fang, 2012).

Ionising radiation exposure results in the generation of reactive oxygen species (ROS) that are highly damaging to cells, DNA, lipids and proteins and consequently the whole cell physiology may be changed (Matuo et al., 2008). Excessive production of ROS have been described as one of the probable pathogenic factors of gastric mucosal and hepatic lesions associated with inflammatory processes (Noh et al., 2011 and Riosa et al., 2010). Both enzymatic and non-enzymatic antioxidant defences can't prevent the ROS increases, thus, they may exert deleterious actions on the gastro hepatic tissues (Rocha et al., 2011). Inflammatory bowel disease including ulcerative colitis and hepatic injury are gastro hepatic disorders induced by ionising-radiation characterized by intestinal inflammation and hepatic tissue damage (Demirel et al., 2011 and Verma et al., 2011). Since the mechanisms of gastro hepatic injury in irradiated animals have not been completely elucidated, many studies have been attempted to find an ideal protective therapy (El-Ghazaly et al., 2011 and Sinha et al., 2011). However, the effects of sildenafil on gastro hepatic dysfunction induced by $\gamma$-rays remain to be established. In this study, several parameters that could potentially affect the sildenafil efficiency were investigated in stomach and hepatic tissues of $\gamma$-irradiated rats.

\section{Materials and Methods}

\section{Animals and Sildenafil administration}

Male Sprague Dawley rats (Holding Company for Biological Products and Vaccines, Cairo, Egypt), weighing 100-122 g, were acclimated to place for 1 week in the animal experimental research laboratory NCRRT, Cairo, Egypt. Rats were placed in plastic cages, subjected to a daily $12 \mathrm{~h}$ light: dark cycle at $22 \pm 3{ }^{\circ} \mathrm{C}$ room temperature and $60 \pm 5 \%$ relative humidity. They were fed maintenance diets according to Reeves (1997). Sildenafil; Viagra, Pfizer, USA, tablets were dissolved in saline. Sildenafil; $1 \mathrm{mg} / \mathrm{kg}$ in $0.2 \mathrm{ml}$ saline were administrated according to Soydan et al. (2009).

\section{The study protocol}

Rats were divided into 4 groups (each of 8 rats): control group; $0.2 \mathrm{ml}$ saline as a vehicle/ day for 5 days were administered to rats through the tail veins, sildenafil group; $1 \mathrm{mg} / \mathrm{kg}$, i.v., in $0.2 \mathrm{ml}$ saline)/ day for 5 days, $\gamma$-rays group; 
received daily $0.2 \mathrm{ml}$ saline for 5 days and exposed to 6 Gy $\gamma$-rays $(0.43 \mathrm{~Gy} /$ min, NCRRT, Cairo, Egypt) after $1 \mathrm{~h}$ of the last injection and sildenafil $+\gamma$-rays group; rats received daily sildenafil doses for 5 days and exposed to 6 Gy $\gamma$-rays after $1 \mathrm{~h}$ of the last injection. All groups were decapitated on the $6^{\text {th }}$ day. Stomach and liver samples were collected and stored at $-70{ }^{\circ} \mathrm{C}$ for subsequent analysis.<smiles>CCCc1nn(C)c2c(=O)[nH]c(-c3cc(S(=O)(=O)N4CCN(C)CC4)ccc3OCC)nc12</smiles>

(1-[3-(4,7-dihydro-1-methyl-7-oxo-3-propyl-1H-pyrazolo[4,3-d]pyrimidin-5-yl)4-ethoxyphenyl]sulfonyl]-4-methylpiperazine. $\mathrm{C}_{22} \mathrm{H}_{30} \mathrm{~N}_{6} \mathrm{O}_{4} \mathrm{~S}$ ).

Fig. 1. Chemical structural of sildenafil.

\section{Analysis of stomach and hepatic tissues}

In stomach and liver samples, MDA content was processed and measured as described by Rocha et al. (2011). NO content was measured by determination of nitrite, the stable end product of NO radicals as described by Green et al. (2000). GSH content was measured according to the method described by Sedlak and Lindsay (1968). CAT, MPO and SOD activities were processed and measured as described by Aebi (1984), Bradley et al. (1982) and Sun et al. (1988), respectively. Proteins were measured as described by Bradford (1976).

\section{Statistical analysis}

Data is expressed as the means \pm S.D. Statistical evaluations were done by Duncan's multiple range test and analysis of variance (ANOVA), using the Statistical Package for Social Studies. Level of significance was set at $P<0.05$.

\section{Results}

Administration of sildenafil alone without $\gamma$-irradiation resulted in nonsignificant changes in all stomach and hepatic tissues parameters studied (Fig. 2-7). The quantification of MDA, NO and GSH in the $\gamma$-irradiated animals showed significant increase in MDA contents in both stomach and hepatic tissues and significant decrease of NO and GSH in both stomach and hepatic tissues as compared to the control groups (Fig. 2-4).

Egypt. J. Rad. Sci. Applic., Vol. 26, No. 1-2 (2013) 


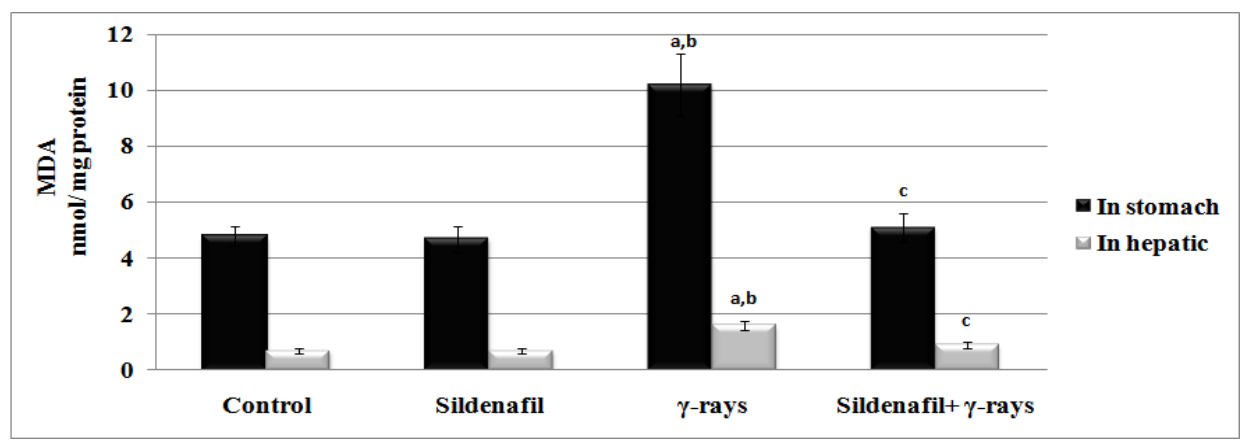

Fig. 2. Effect of sildenafil and/ or $\gamma$-rays on stomach and hepatic MDA in rat groups.

a, significantly different from the control group.

b, significantly different from the sildenafil group.

c, significantly different from the $\gamma$-rays group.

In sildenafil $+\gamma$-rays groups of rats, MDA, NO and GSH contents were reversed and became insignificant in comparison with corresponding control groups in both stomach and hepatic tissue, Fig. 2-4.

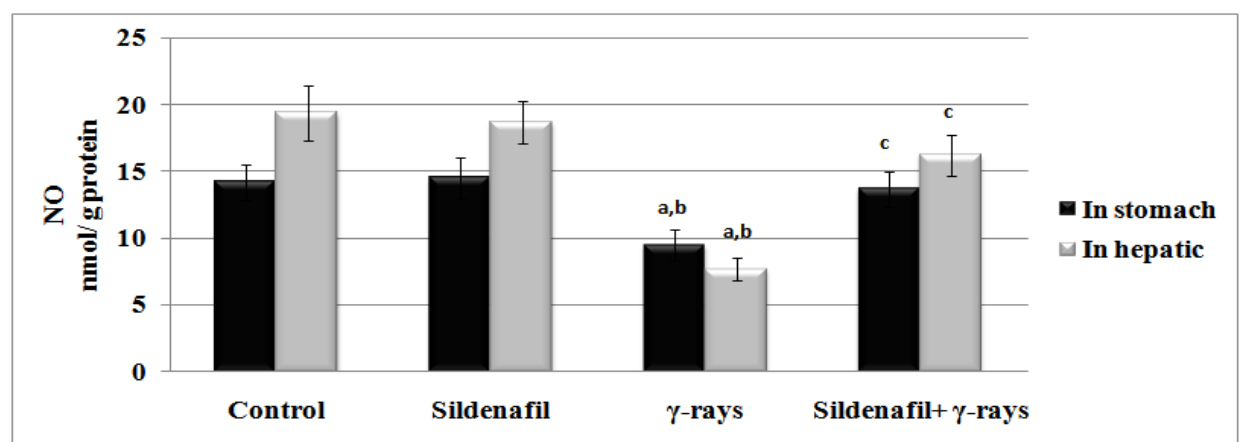

Fig. 3. Effect of sildenafil and/ or $\gamma$-rays on stomach and hepatic NO in rat groups.

Legends as in Fig. 1.

The estimation of the activities of MPO, SOD and CAT in the $\gamma$-irradiated animals showed significant increase of MPO activities in both stomach and hepatic tissues and decrease of SOD and CAT activities in the two tissues as compared to the control groups, Fig. 5-7. In sildenafil $+\gamma$-rays groups, MPO and SOD activities were changed significantly compared to the $\gamma$-rays groups in stomach tissue and was insignificant from the control groups in hepatic tissue only, while the CAT activity was significantly increased in stomach and hepatic tissues. The increased CAT activity was insignificant in stomach tissue only as compared to the control group, Fig. 5-7.

Egypt. J. Rad. Sci. Applic., Vol. 26, No. 1-2 (2013) 


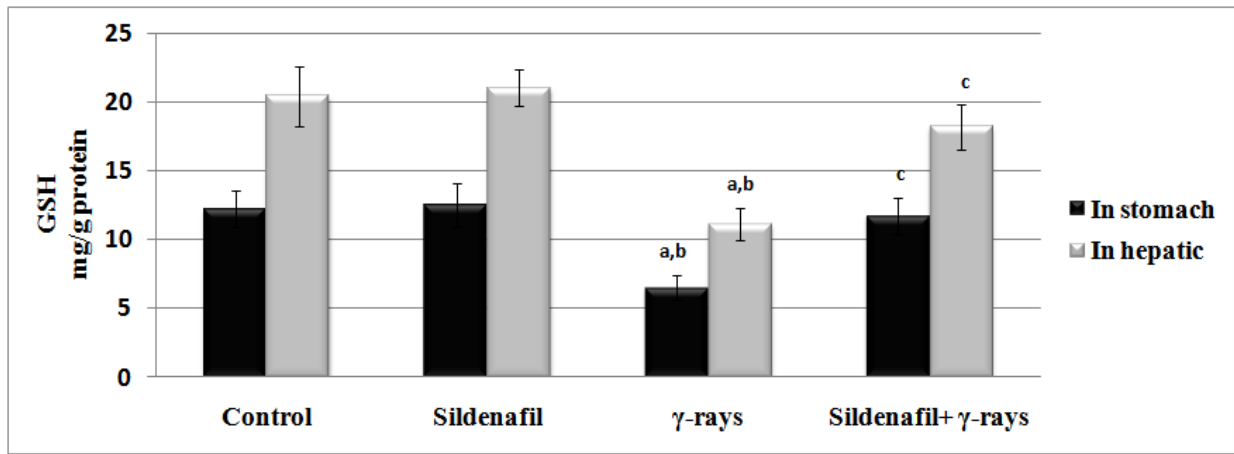

Fig. 4. Effect of sildenafil and/ or $\boldsymbol{\gamma}$-rays on stomach and hepatic GSH in rat groups.

Legends as in Fig. 1.

CAT activities were significantly increased in stomach and hepatic tissues. The increased became insignificant in stomach tissue only in comparison with corresponding control group, Fig. 4-6.

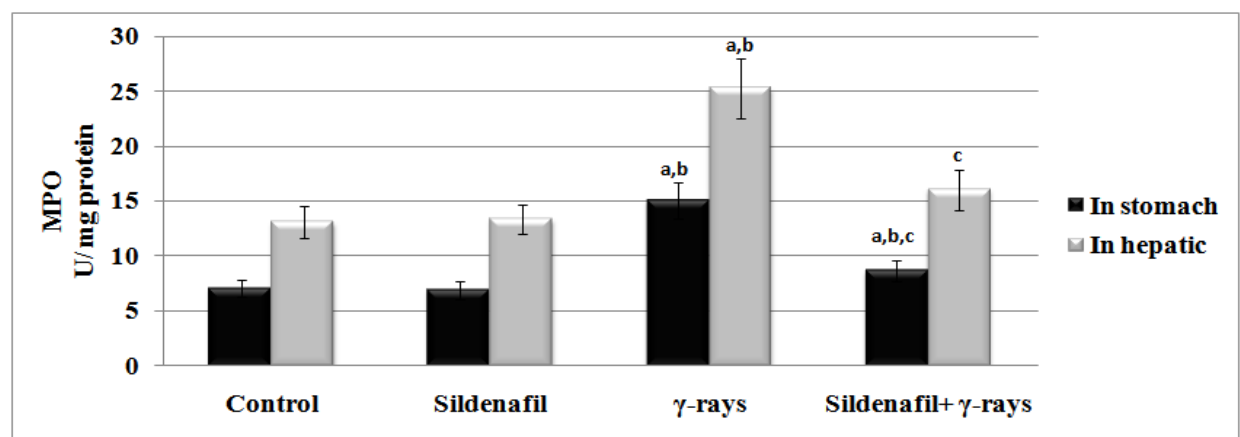

Fig. 5. Effect of sildenafil and/ or $\gamma$-rays on stomach and hepatic MPO in rat groups.

Legends as in Fig. 1.

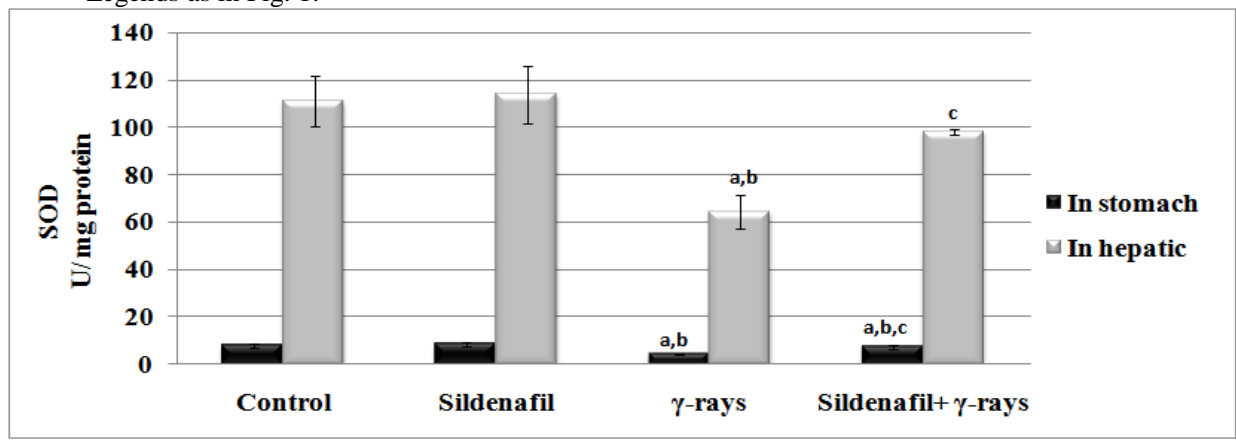

Fig. 6. Effect of sildenafil and/ or $\boldsymbol{\gamma}$-rays on stomach and hepatic SOD in rat groups.

Legends as in Fig. 1. 


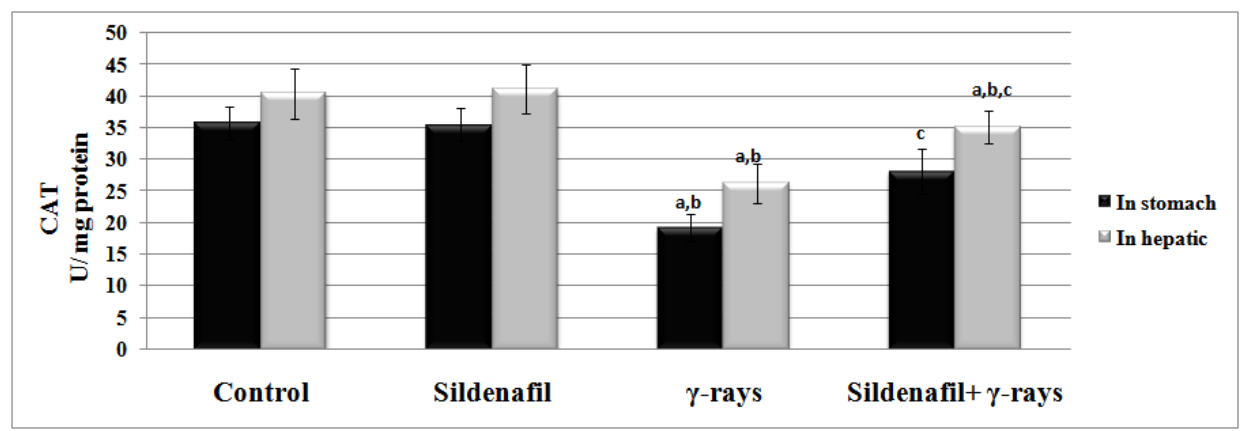

Fig. 7. Effect of sildenafil and/ or $\gamma$-rays on stomach and hepatic CAT in rat groups.

Legends as in Fig. 1.

\section{Discussion}

The cells of the gastric tract have an antioxidant defence system capable of preventing the cytotoxicity of ROS through mechanisms that involve the action of enzymes and compounds which bind to oxygen radicals and prevent their harmful actions (Riosa et al., 2010). Sildenafil, acting via nitric oxide (NO)dependent mechanism, prevented indomethacin-induced gastropathy (gastric mucosa damage) possibly through a reduction of leukocyte adhesion and maintenance of gastric blood flow (Aydinli et al., 2007 and Santos et al., 2005). Liver-related diseases are still among the leading causes of morbidity and mortality all over the world (Park et al., 2012). Since oxidative stress is one of the main causes of radiation-induced liver injury (Verma et al., 2011). The authors suggest that, the ability of sildenafil to suppress oxidative stress in hepatic tissues can be potent candidates for liver protection.

The degree of lipid peroxidation in tissues was measured by determining the amount of MDA, which relate directly to the level of injury to tissues (Kerman et al., 2011) and also significantly associated with increased apoptosis in gastric tissue of animals ( $\mathrm{Li}$ et al., 2011). In the present study, administration of sildenafil before irradiation decreased the level of MDA in both stomach and hepatic tissues when compared with the irradiated groups. These decreases in MDA levels suggest a protective effect of sildenafil on rat tissue due to its antioxidant effect and the inhibition of ROS. In accordance with several studies, sildenafil has an anti-inflammatory property via the inhibition of ROS (Yildiz et al., 2011).

Egypt. J. Rad. Sci. Applic., Vol. 26, No. 1-2 (2013) 
Interplay between inflammatory reaction and the cell membrane of organs causes relative NO-deficiency as a result of reaction of $\mathrm{NO}$ with oxygen radicals (Bongartz et al., 2005). Exposure of animals to $\gamma$-rays caused significant decreases in NO levels in stomach and liver tissue homogenates. Excess production of $\mathrm{O}_{2}^{-}$in pathologic conditions such as irradiation syndrome causes the formation of peroxynitrite (Ortega Mateo and de Artinano, 2000). In the present study, administration of sildenafil significantly increased the NO levels in stomach and hepatic tissues compared with irradiated groups suggesting a possible physiological response by decreasing oxidative damage as a result of increasing NO production. PDE-5 inhibitors augment the action of NO that inhibits the expression of NADPH-oxidase (Arikan et al., 2010), which in turn reduces the irradiation-injury in the tissues.

Several studies reported that the MPO activity level could be a marker of endothelial dysfunction (Ahluwalia et al., 2004) and an indicator of neutrophil infiltration in ulcerogenic lesions (Rocha et al., 2011). The presence of oxygen free radicals (Kutsuna et al., 2010), inflammatory mediators and extra vacated leukocytes (Hassoun et al., 2011) may also contribute to the physiological dysfunction observed after ischemia-reperfusion injury in gastro hepatic tissue. Furthermore, gastric muscle is very vulnerable to inflammation and during the reperfusion period, the generation of oxygen free radicals interferes with the function of cells by disrupting ionic homeostasis (Kutsuna et al., 2010). In the present study, exposure to $\gamma$-rays resulted in excessive MPO production, as recognized by Sener et al. (2006). Administration of sildenafil significantly decreased the MPO activity in stomach and hepatic tissues comparing with irradiated groups, where, sildenafil prevents oxidant generation, cytokine production and neutrophil accumulation (Iseri et al., 2009).

SOD and CAT are the most important enzymes in the antioxidant defence system, which is responsible for protecting tissues against the deleterious effects of ROS (Tawfik et al., 2010). Decreased tissue SOD and CAT activities in the irradiated groups may have occurred as a result of consumption of enzymes by ROS during oxidative stress. The beneficial effect of sildenafil administration against $\gamma$-irradiation-induced damage was confirmed by the increased level of both SOD and CAT in rat stomach and hepatic tissues. Recently it was found that sildenafil increases SOD and CAT activities in testicular injury in rats (Beheshtian et al., 2008).

Egypt. J. Rad. Sci. Applic., Vol. 26, No. 1-2 (2013) 
Sildenafil has comparable effect on portal hemodynamics, improves portal liver perfusion and induces a drop of portal pressure (Bremer et al., 2007). Furthermore, the absence of hepatotoxicity in irradiated rats treated with sildenafil is consistent with the tolerance of sildenafil demonstrated in alcoholfed animal models (Boniface et al., 2010). In addition, it has been shown that sildenafil pre-treatment has a protective effect against ileal dysfunction and damage induced by intestinal irradiation in the rat (Soydan et al., 2009).

\section{Conclusion and further research}

In conclusion, sildenafil was able to reduce gastro hepatic injury induced in irradiated rats. These findings show that sildenafil is able to decrease oxidative stress event associated with the injury induced by $\gamma$-rays-exposure.

Further studies that support these results should be performed in models more comparable to clinical cases of other tissues $\gamma$-rays-injury with regard to the dose and timing of drug administration.

\section{References}

Aebi, H. (1884) Catalase in vitro. Methods Enzymol., 105, 121.

Ahluwalia, A., Foster, P., Scotland, R. S., McLean, P. G., Mathur, A., Perretti, M., Moncada, S. and Hobbs, A. J. (2004) Anti-inflammatory activity of soluble guanylate cyclase: cGMP-dependent down-regulation of P-selectin expression and leukocyte recruitment. Proc. Natl. Acad. Sci., 101, 1386.

Arikan, D. C., Bakan, V., Kurutas, E. B., Sayar, H. and Coskun, A. (2010) Protective effect of tadalafil on ischemia/reperfusion injury of rat ovary. $J$. Pediatr. Surg., 45, 2203.

Aydinli, B., Yildirgan, I. M., Ozturk, G., Atamanalap, S. S., Polat, K. Y., Kiziltunc, A., Basoglu, M., Gundogdu, Suleyman, H., Kiziltunc, A., Gursan, N. and Oren1, D. (2007) The role of sildenafil citrate in the protection of gastric mucosa from nonsteroidal anti-inflammatory drug-induced damage. Turk. $J$. Trauma \& Emerg. Surg., 3, 268.

Beheshtian, A., Salmasi, A., Payabvash, S., Kiumehr, S., Ghazinezami, B., Rahimpour, S., Tavangar, S. and Dehpour, A. (2008) Protective effects of sildenafil administration on testicular torsion/detorsion damage in rats. World J. Urol., 26, 197.

Bongartz, L., Ceamer, M., Doevendars, P., Joles, J. and Braam, B. (2005) The sever cardiorenal syndrome: 'Guyton revisted”. Eur. Heart J., 26, 11.

Egypt. J. Rad. Sci. Applic., Vol. 26, No. 1-2 (2013) 
Boniface, S., Gaubert, J., Blanc, A., Botta-Fridlund, D., Renard, S., Habib, G. and Reynaud-Gaubert, M. (2010) Functional improvement in a patient with cirrhosis and portopulmonary hypertension treated by sildenafil for 2 years. Resp. Medic. CME, 3, 263.

Bradford, M. M. (1976) A rapid and sensitive method for the quantitation of microgram quantities of protein utilizing the principle of protein-dye binding. Anal. Biochem., 72, 248.

Bradley, P. P., Christensen, R. D. and Rothstein, G. (1982) Cellular and extracellular myeloperoxidase in pyogenic inflammation. Blood, 60, 618.

Bremer, H., Kreisel, W., Roecker, K., Dreher, M., Koenig, D., Kurz-Schmieg, A., Blum, H., Roessle, M. and Deibert, M. (2007) Phosphodiesterase 5 inhibitors lower both portal and pulmonary pressure in portopulmonary hypertension: a case report. J. Med. Case Rep., 1, 46.

Demirel, U., Harputluoglu, M., Us, S., Kaya, E., Sahin, N., Aydin, N., Gursoy, S., Bilgic, Y., Demirel, M., Bulut, T., Selcuk, E. and Aladag, M. (2011) The effects of Teucrium polium on ionizing radiation-induced intestinal damage in rats. Acta Gastroenterol. Belg., 74, 491.

Duffin, R., Shaw, C. A. and Rossi, A. G. (2008) Sildenafil reduces alcohol-induced gastric damage: just say 'NO'. Br. J. Pharmacol., 153, 623.

El-Ghazaly, M. A., Rashed, R. R. and Khayyal, M. T. (2011) Anti-ulcerogenic effect of aqueous propolis extract and the influence of radiation exposure. Int. $J$. Radiat. Biol., 87, 1045.

Eriksson, C., Gustavsson, A., Kronvall, T. and Tysk, C. (2011) Hepatotoxicity by bosentan in a patient with portopulmonary hypertension: a case-report and review of the literature. J. Gastrointestin. Liver Dis., $20,77$.

Green, L. C., Tannenbaun, S. R. and Goldman, P. (2000) Nitrate syntesis in Parkinson's disease using the model of the 6-hydroxydopamine and MPTP. Ann. NY Acad. Sci., 899, 262.

Hassoun, P. M. (2011) Pulmonary arterial hypertension in china: promising news and some surprises. Chest, 140, 276.

Iseri, S. O., Ersoy, Y., Ercan, F., Yuksel, M., Atukeren, P., Gumustas, K. and Alican, I. (2009) The effect of sildenafil, a phosphodiesterase-5 inhibitor, on acetic acid-induced colonic inflammation in the rat. J. Gastroenterol. Hepatol., 24, 1440.

Kerman, M., Kanter, M., Coşkun, K. K., Erboga, M. and Gurel, A. (2011) Neuroprotective effects of caffeic acid phenethyl ester on experimental traumatic brain injury in rats. J. Mol. Histol., 43, 49.

Egypt. J. Rad. Sci. Applic., Vol. 26, No. 1-2 (2013) 
Khan, J. N., Patel, N., Steeds, R. and Varma, C. (2012) Sildenafil: a novel therapy in the management of cardiac syndrome X. N Z Med. J., 125, 101.

Kutsuna, S. Tsuruta, R., Fujita, M., Todani, M., Yagi, T., Ogino, Y., Igarashi, M., Takahashi, K., Izumi, T., Kasaoka, S., Yuasa, M. and Maekawa, Y. (2010) Cholinergic agonist physostigmine suppresses excessive superoxide anion radical generation in blood, oxidative stress, early inflammation, and endothelial injury in rats with forebrain ischemia/reperfusion. Brain Res., 1313, 242.

Matuo, Y., Nishijima, S., Ikeda, T. and Shimizu, K. (2008) Radical scavenging effect of naturally-occurring epigallocatechin gallate against oxidative damage caused by gamma-ray radiation. Radioisot., 57, 723 .

Li, N. S., Luo, X. J., Zhang, Y. S., He, L., Liu, Y. Z., Peng, J. (2011) Phloroglucinol protects gastric mucosa against ethanol-induced injury through regulating myeloperoxidase and catalase. Fundam. Clin. Pharmacol., 25, 462.

Liu, Z. and Fang, L. (2012) Phosphodiesterase-5 inhibitor and rat lung ischemiareperfusion injury. Asian Cardiovasc. Thorac. Ann., 20, 42.

Noh, J., Kim, Y., Gang, G., Hwang, J., Kim, S., Kim, Y., Lee, H. and Lee, C. (2011) Hepatoprotective effect of platycodon grandiflorum against chronic ethanoliduced oxidative stress in C57BL/6 Mice. Ann. Nutr. Metab., 58, 224.

Ortega Mateo, A. and de Artinano, A. A. (2000) Nitric oxide reactivity and mechanisms involved in its biological effects. Pharmacol. Res., 42, 421.

Park, H., Park, Y., Lee, Y., Noh, S., Sung, E. and Choi, I. (2012) Effect of oral administration of water-soluble extract from citrus peel (Citrus unshiu) on suppressing alcohol-induced fatty liver in rats. Food Chem., 130, 598.

Reeves, P. G. (1997) Components of the AIN-93 diets as improvements in the AIN76A diet. J. Nut., 127(Suppl. 5): 838S.

Riosa, E., Rocha, N., Venâncio, E., Moura, B., Feitosa, M., Cerqueira, G., Soares, P., Woods, D., Florenco de Sousa, F., Leal, L. and Fonteles, M. (2010) Mechanisms involved in the gastroprotective activity of esculin on acute gastric lesions in mice. Chem. Biolog. Interact., 188, 246.

Rocha, N., de Oliveira, G., de Araujo, F., Rios, E., Carvalho, A., Vasconcelos, L., Macedo, D., Soares, D., De Sousa, D. and de Sousa, F. (2011) (-)- $\alpha-$ Bisabolol-induced gastroprotection is associated with reduction in lipid peroxidation, superoxide dismutase activity and neutrophil migration. Eur. J. Pharmaceut. Sci., 44, 455.

Rodriguez-Iturbe, B., Ferrebuz, A., Vanegas, V., Quiroz, Y., Espinoza, F., Pons, H. and Vaziri, N. (2005) Early treatment with cGMP phosphodiesterase inhibitor ameliorates progression of renal damage. Kidney Int., 68, 2131.

Egypt. J. Rad. Sci. Applic., Vol. 26, No. 1-2 (2013) 
Santos, C., Souza, M., Gomes, A., Lemos, H., Santos, A., Cunha, F. and Wallace, J. (2005) Sildenafil prevents indomethacin-induced gastropathy in rats: role of leukocyte adherence and gastric blood flow. Br. J. Pharmacol., 146, 481.

Sedlak, J. and Lindsay, R. (1968) Estimation of total, protein-bound, and nonprotein sulfhydryl groups in tissue with Ellman's reagent. Anal. Biochem., 25, 192.

Sener, G., Kabasakal, L., Atasoy, B. M., Erzik, C., Velioglu-Ogunç, A., Çetinel, S., Contuk, G., Gedik, N. and Yegen, B. C. (2006) Propylthiouracil-induced ypothyroidism protects ionizing radiation-induced multiple organ damage in rats. J. Endocrinol., 189, 257.

Sinha, M., Das, D. K., Bhattacharjee, S., Majumdar, S. and Dey, S. (2011) Leaf extract of Moringa oleifera prevents ionizing radiation-induced oxidative stress in mice. J. Med. Food, 14, 1167.

Soydan, G., Sokmensuer, C., Kılınc, K. and Tuncer, M. (2009) The effects of sildenafil on the functional and structural changes of ileum induced by intestinal ischemia-reperfusion in rats. Eur. J. Pharmacol., 610, 87.

Sun, Y., Oberley, L. W. and Li, Y. (1988) A simple method for clinical assay of superoxide dismutase. Clin. Chem., 34, 497.

Tawfik, S. S., El-Tawil, G. A. and Elkhouly, W. A. (2010) Ferulic acid as a potential antioxidant therapeutic agent in $\gamma$-irradiated rats. Egypt. J. Rad. Sci. Aplicc., 23, 261.

Verma, P., Sharma, P., Parmar, J., Sharma, P. and Goyal, P. K. (2011) Amelioration of radiation-induced hematological and biochemical alterations in Swiss albino mice by Panax ginseng extract. Integr. Cancer Ther., 10, 77.

Yildiz, H., Durmus, A., Simsek, H. and Yaman, I. (2011) Effects of sildenafil citrate on torsion/detorsion-induced changes in red blood cell and plasma lipid peroxidation, antioxidants, and blood hematology of male rats. Eur. J. Obstet. Gynecol. Reprod. Biol., 159, 359.

(Received: 03/03/2013;

accepted: 16/04/2013) 


$$
\begin{aligned}
& \text { التأثيرات الوقائية للسيلدينافيل علي المعدة و الكبد في الجرذان } \\
& \text { المعرضة لأثثعة جاما } \\
& \text { سامح سليمان توفيق و صفوت فريد سلامة } \\
& \text { قسمي البحوث الصحية الإثعاعية و بيولوجيا الإثـعاع ، المركز القومي لبحوث }
\end{aligned}
$$

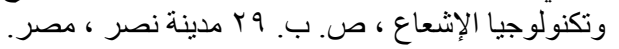

السيلدينافيل مثبط فعال للفوسفو ديستير از ـ (PDE-5) يؤدي إلي وفرة

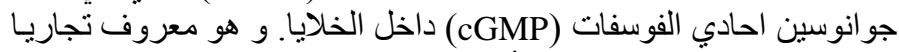

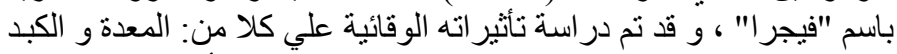

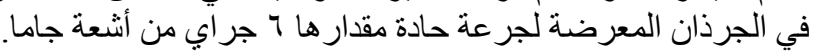

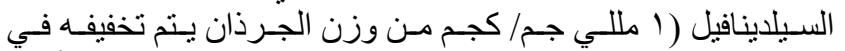

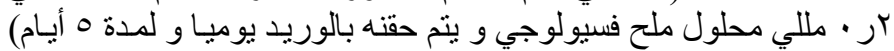

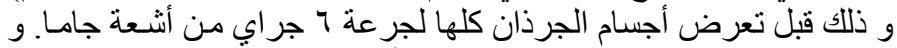

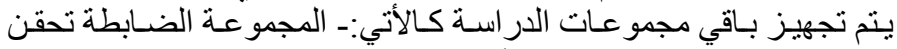

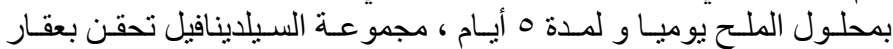

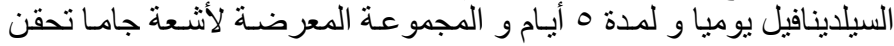

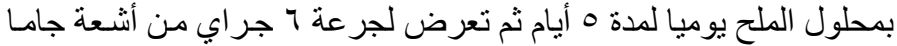

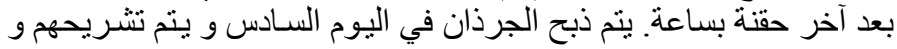

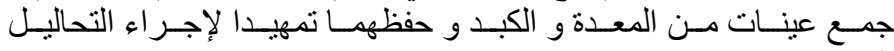

أظهرتِ النتائج أن تعرض الجرذان لأشعة جاما أدي إلي ظهور زيادة

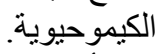

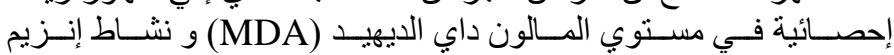

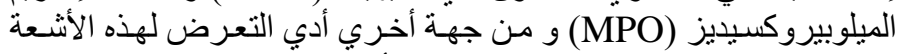

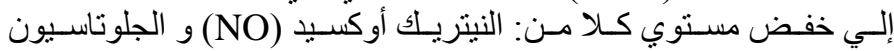

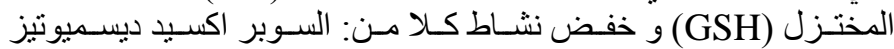

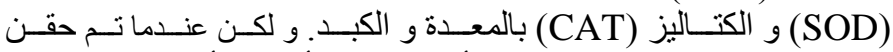

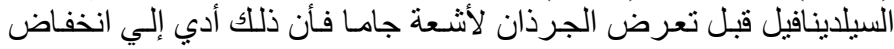

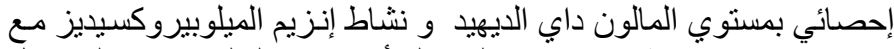

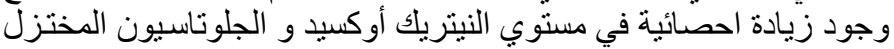

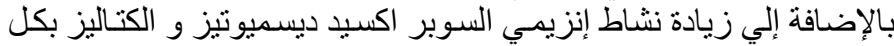
من: المعدة و الكبد مقارنة بمستوياتهم بالمجمو عة التي تعرضت لألتئ لأشعة جاما الخلاصة: تثنير النتائج إلي إمكانية استخدام السيلدينافيل كعلاج و قائي

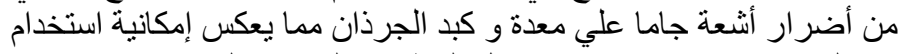
هذا العقار كعلاج و اقي من الاختلال الوظيفي بالمعدة و الكبد.

Egypt. J. Rad. Sci. Applic., Vol. 26, No. 1-2 (2013) 